\title{
The Relationship of Limb Muscle Power, Balance, and Coordination with Instep Shooting Ability: A Correlation Study in Under-18 Football Athletes
}

\author{
Erick Burhaein $^{1, *}$, Bagus Kanang Ibrahim², Ratko Pavlovic ${ }^{3}$ \\ ${ }^{1}$ Doctoral Program of Sports Education, School Postgraduates Studies, Universitas Pendidikan Indonesia, Bandung, 40154, Jawa Barat, \\ Indonesia \\ ${ }^{2}$ Bachelor of Sports Science, Faculty of Sports Science, Universitas Negeri Yogyakarta, Yogyakarta 55281, Daerah Istimewa \\ Yogyakarta, Indonesia \\ ${ }^{3}$ Faculty of Physical Education and Sport, University of East Sarajevo, Lukavica, 71126, East Sarajevo, Bosnia dan Herzegovina
}

Received August 26, 2020; Revised October 9, 2020; Accepted October 25, 2020

\section{Cite This Paper in the following Citation Styles}

(a): [1] Erick Burhaein, Bagus Kanang Ibrahim Ratko Pavlovic, "The Relationship of Limb Muscle Power, Balance, and Coordination with Instep Shooting Ability: A Correlation Study in Under-18 Football Athletes," International Journal of Human Movement and Sports Sciences, Vol. 8, No. 5, pp. 265 - 270, 2020. DOI: 10.13189/saj.2020.080515.

(b): Erick Burhaein, Bagus Kanang Ibrahim, Ratko Pavlovic (2020). The Relationship of Limb Muscle Power, Balance, and Coordination with Instep Shooting Ability: A Correlation Study in Under-18 Football Athletes. International Journal of Human Movement and Sports Sciences, 8(5), 265-270. DOI: 10.13189/saj.2020.080515.

Copyright $\bigcirc 2020$ by authors, all rights reserved. Authors agree that this article remains permanently open access under the terms of the Creative Commons Attribution License 4.0 International License

\begin{abstract}
The purpose of this study was to examine the relationship between leg muscle power, balance, coordination, and shooting skills in soccer. Participants in this study used 89 soccer athletes with an age range of $15-18$ years $(M=17.6$; $S D: 1.30)$. The research instrument used a coordination test (soccer wall volley test), balance test (modified bass test), leg muscle power (standing long jump test or broad jump), and shooting skills test. Data collection techniques, namely by measuring tests and measurements by the implementation procedure. Data analysis in this study was using Pearson correlation and regression analysis with the help of the IBM SPSS 24 application. The results showed that: 1) There was a relationship between leg muscle power and shooting ability using instep; 2) There is a relationship between balance and the ability to shoot using the instep; 3) There is a coordination relationship with the ability to shoot using the instep; and 4) There is a relationship between leg muscle power, balance, and coordination with the shooting ability using the instep. Recommendations for further research are suggested to involve other independent variables $(\mathrm{X})$ that are relevant to this study, such as leg length, running speed, and angle of impact.
\end{abstract}

Keywords Limb Muscle Power, Balance,
Coordination, Shooting, Soccer

\section{Introduction}

Football is a sport that is increasingly favored by all levels of society [1]. Football can be played by anyone, both men and women, young and old [1], [2]. Through this sports activity, there are many benefits, especially in physical, mental, and social growth. The sport of football is currently experiencing very rapid development, as evidenced by the emergence of professional and amateur football clubs and football athletes both at the school and college levels [1], [3]. Supported by the frequent holding of club tournaments and students and student events from regional to national levels.

Since the sport of football develops in various countries, skills are needed to master the sport. Football is a complex sport because it requires special techniques and tactics [4]. Every player should be able to master the basic techniques of playing football. Players must be equipped with good basic techniques, players who have good basic techniques tend to be able to play football well too. There are several 
basic techniques in soccer, such as receiving, shooting, passing, chipping, heading, and dribbling. Also, every football player must be equipped in terms of physical condition, because the game of football is different from other sports [5]. The characteristics of the sport of football are that it requires endurance, speed, endurance, coordination, strength, and agility for a relatively long time.

There are various techniques and movements that players can do on the field so that on the field there are various combinations of techniques and movements that support players in possession of the ball to achieve a victory [6], [7]. In reality on the field, the game of football is dominated by mastery of fast passing balls between players and good shooting skills. For example, professional football teams can control the ball very well, flow the ball fast, pass accurately, dribble well, shoot well, support each other's teammates, open space for movement, solid cooperation, and also own individual skills. the players make this team a good team [8].

In the game of football, the dominant thing to do is to kick, which is passing and shooting or shooting. This technique looks easy, but it requires concentration and the right time to take a shot that is taken towards the goal or becomes a goal [9], [10]. Often people see in football matches, shooting is a powerful weapon to score goals. In soccer, shooting can be done in various ways, namely by using the instep, toe, inner foot, and heel. Nonetheless, instep shooting is more effective and more done by players.

That's because, to shoot well, one has to be able to do complex movements. To shoot well, people must have good physical abilities, therefore people are required to be able to shoot well under the pressure of the game, tight space, physically tired, and limited time. Physical is the basis of athletic achievement because technique, tactics, and mentality can be developed properly if they have good physical qualities. [11], [12]. Researchers see that movement can be done if the player has good coordination, balance, and leg muscle power.

The factors that cause the less than optimal shooting accuracy in soccer games are the lack of awareness of the athletes to practice basic techniques of shooting the ball at the goal [13]. The game of football is not only the basic technique of playing football, but there are still other important elements, namely the element of the physical ability which consists of strength, endurance, explosive power, speed, flexibility, agility, coordination, and balance [1], [14]. Many motor skills support the implementation of football, including coordination, agility, flexibility, speed, and balance

To achieve maximum results in shooting accuracy, coordination training is very important and absolutely must be owned by a football player [6], [15]. The better the eye-foot coordination, the better the shooting accuracy will be. In general, this is because coordination is needed in every form of movement in sports. In particular, in the game of football, a player is required to make very complex movements. This very complex movement can be done well if a player has good coordination of the eyes, hands, feet, and all parts of the body [4].

Shooting in football requires one to have a good balance. This is because in shooting people only rely on one leg and the other leg swings to kick the ball with the help of hands to balance the body [16].

Leg muscle power is needed to support the leg so that it can kick the ball hard [17]. The rapid flow of the ball that is kicked by the player will make it more difficult for the opponent's goalkeeper to block the ball, so the chances of a goal will be greater [8].

Based on the description above, the researcher wanted to examine the relationship between leg muscle power, balance, coordination, and shooting skills in soccer. As for the theme of the problem, the researcher describes the following four research questions:

1) Is there a relationship between leg muscle power and the ability to shoot using the instep?

2) Is there a relationship between balance and the ability to shoot using instep?

3) Is there a relationship between coordination and the ability to shoot using the instep?

4) Is there a relationship between leg muscle power, balance, and coordination with the ability to shoot using the instep?

\section{Materials and Methods}

\subsection{Research Method}

This study used a quantitative research approach, then the design used was a correlational research design [18], [19]. The research design is as shown in Figure 1 as follows.

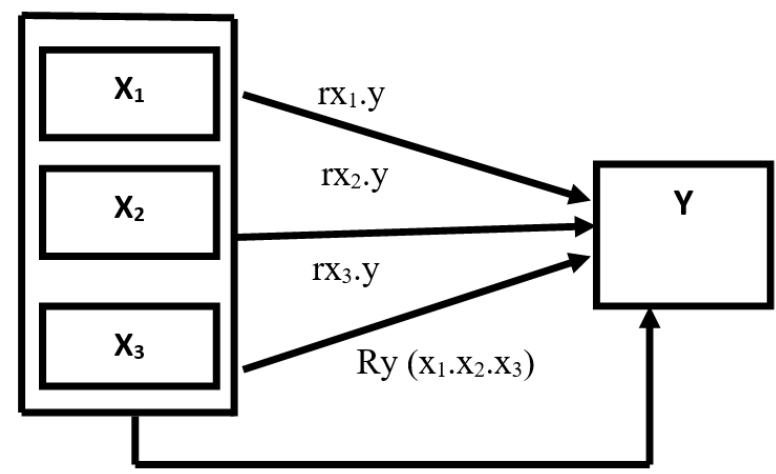

Figure 1. Research design

\subsection{Participant}

Participants in this study used 89 male soccer athletes with an age range of $15-18$ years $(M=17.6$; SD: 1.30$)$. 


\subsection{Instruments}

The research instrument used to measure four variables amounted to four instruments, as follows. Leg muscle power, using a standing long jump test or broad jump instrument [20]. Balance, with modified BASS balance test, with validity 0.46 [21], [22] and reliability 0.75 [23]. Coordination, using the soccer wall volley test instrument [24]. Shooting skills, with a shooting test instrument [25].

\subsection{Data Collection Technique}

The method used in this research is a survey with data collection techniques using tests and measurements [18], [26]. Before the measurement is carried out, the instrument used is carried out using an indication to determine whether the tool used is still good or not. The research begins with warming up the testicles to reduce the risk of injury during the test. Previously, the researcher gave instructions that must be done by the participants so that there were no errors during the test. After that, measurements were taken for each variable.

\subsection{Data Analysis}

Data analysis in this study is to use two analyzes. Research questions 1-3 are with the Pearson correlation analysis. Research question 4 is a multiple-regression analysis. All analyzes were performed with the help of the IBM 24 SPSS application.

\section{Results}

\subsection{Hypothesis Testing: Pearson Correlation Analysis}

The Karl Pearson Product-moment correlation analysis is used to test the hypotheses. Hypothesis $1-3$ are as follows:

Hypothesis 1: There is a significant relationship between leg muscle power and the ability to shoot using the instep.

Hypothesis 2: There is a significant relationship between balance and the ability to shoot using instep.

Hypothesis 3: There is a relationship between coordination and the ability to shoot using the instep.

Table 1. Product-moment correlation result

\begin{tabular}{cccc}
\hline Variable & $\mathbf{r}$ & $\mathbf{R}^{2}$ & $\begin{array}{l}\mathbf{p}<\mathbf{0 . 0 1} \\
\text { (2-tailed) }\end{array}$ \\
\hline $\mathrm{X} 1 . \mathrm{Y}$ & 0.705 & 0.232 & $0.000^{* *}$ \\
\hline $\mathrm{X} 2 . \mathrm{Y}$ & 0.773 & 0.256 & $0.000^{* *}$ \\
\hline $\mathrm{X} 3 . \mathrm{Y}$ & 0.803 & 0.345 & $0.000^{* *}$ \\
\hline
\end{tabular}

The correlation coefficient $r_{x 1 y}$ shows the value of 0.705 , which indicates that leg muscle power and the ability to shoot using the instep. The determination coefficient $\left(\mathrm{R}^{2}{ }_{\mathrm{x} 1 \mathrm{y}}\right)$ is 0.232 , which means that the leg muscle power variable has an effect of $23.2 \%$ on the ability to shoot using the instep variable, and the rest is influenced by other variables (factors). The significance value of $r_{x 1 y}$ is 0.000 and less than 0.05 ( $\mathrm{p}<0.05 ; 0.000<0.05$ ); thus, Hypothesis 1 is accepted. This means, that there is a significant relationship between leg muscle power and the ability to shoot using the instep.

The correlation coefficient $r_{x 2 y}$ shows the value of 0.773 , which indicates that balance and the ability to shoot using instep. The determination coefficient $\left(\mathrm{R}^{2} \times 2 \mathrm{y}\right)$ is 0.256 ; the balance variable has an effect of $25.6 \%$ on the ability to shoot using instep, and the rest is influenced by other variables (factors). The significance value of $r_{x 2 y}$ is 0.000 or less than 0.05 (p <0.05; $0.000<0.05)$; therefore, Hypothesis 2 is accepted, meaning that, there is a significant relationship between balance and the ability to shoot using instep.

The correlation coefficient is $r_{x 3 y}$ with a value of 0.803 , which indicates that coordination and ability to shoot using the instep. The determination coefficient $\left(\mathrm{R}^{2}{ }_{\mathrm{x} 3 \mathrm{y}}\right)$ is 0.345 , which means that coordination gives a $34.5 \%$ effect on the ability to shoot using the instep variable, and the rest is influenced by other variables (factors). The significance value of $r_{x 3 y}$ is 0.000 and less than 0.05 ( $p<0.05 ; 0.000$ $<0.05$ ), so Hypothesis 3 is accepted. This means that there is a significant relationship between coordination and the ability to shoot using the instep.

\subsection{Hypothesis Testing: Multiple-regression Analysis}

The multiple regression analysis is selected to analyze the proposed fourth hypothesis, which 4-states that:

Hypothesis 4: There is a significant relationship between leg muscle power, balance, and coordination with the ability to shoot using the instep.

The multiple regression analysis is used to test Hypothesis 4. The following is the result of the analysis. Table 2 shows the results found.

Table 2. Multiple-Regression Analysis

\begin{tabular}{cccc}
\hline Variable & $\begin{array}{c}\text { Regression } \\
\text { Coefficient (b) }\end{array}$ & Sig. & Conclusion \\
\hline Leg Muscle Power & 0.012 & 0.000 & Significant \\
Balance & 0.021 & 0.000 & Significant \\
Coordination & 0.018 & 0.000 & Significant \\
Constant $=3.322$ & & & \\
$\mathrm{R}^{2}=0.706$ & & & \\
$\mathrm{~F}_{1}=12.511$ & & & \\
Sig. $=0.000$ & & & \\
\hline
\end{tabular}

Based on the test result, the calculated F value of 12.511 is obtained with a significance level of 0.000 . Because the significance value of $r_{x 123 y} 0.000$ is less than $0.05(p<0.05$; $0.000<0.05)$, Hypothesis 4 is accepted. Therefore, there is a significant relationship between leg muscle power, balance, and coordination with the ability to shoot using the 
instep.

The $\mathrm{R}^{2}$ test result in this study obtains a value of 0,706 . This shows that teacher performance is influenced (70.6\%) by leg muscle power, balance, and coordination, while the rest $(29.4 \%)$ is influenced by other variables (factor) not included in this study.

\section{Discussion}

\subsection{Leg Muscle Power (X1) with Instep Shooting Ability (Y)}

Leg muscle power is the tension exerted by the leg muscles against the tension or load with maximum effort to move the muscles. Every athlete in any sport is required to have good physical condition to support the desired achievement. The physical condition can be improved by practicing. One of the factors that play a role in the achievement of shooting football is the physical condition, including the power of the leg muscles [27]. In other words, to achieve a kick there must be an element of physical condition, especially the leg muscle power used to lift the thigh and exert a repulsive force when kicking the ball. The power of a person's leg muscles plays an important role in increasing the frequency of a person's running steps because the frequency of steps is the multiplication of the leg muscle power and the muscle speed in walking.

The findings in this study explain that students who have good leg muscle power will have good shooting skills using the instep. Also, the results showed that leg muscle power is important for every player to have and improve in increasing the ability to shoot using instep.

The results of this study are following the theory, that the ability of a football athlete in shooting football is influenced by leg muscle power because the combination of strength and maximum speed gives an optimal effect on ball kicks [16], [27]. This leg muscle power is used when running dribbling and kicking the ball, with strong leg muscles the kick will be stronger. A football player must have strong feet, strong ankles, strong knees, and strong legs to carry a heavy body.

\subsection{Balance (X2) with Instep Shooting Ability (Y)}

Balance is a person's ability to control the muscle nerve organs so that they can control movements properly and correctly [21]. The findings in this study explain that students who have good balance will have good shooting skills using the instep. Also, the results showed that balance is important for every player to improve the ability to shoot using instep.

When shooting in a running condition, the body is unbalanced because it is carried out with one-foot support and holding all limbs, it is necessary to have maximum body balance so that the shooting is carried out at the desired target. This is reinforced by theory, that without having a balance, football players will not be able to shoot properly and accurately, so balance is a component that a football player needs to have [16], [21]. Besides, the existence of balance will be able to increase strength and endurance, and also can easily control the position of the body when making kicks and also after taking kicks. Like kicking long or close range.

\subsection{Coordination (X3) with Instep Shooting Ability (Y)}

Coordination is a combination of the motion of two or more joints, which are related to each other in producing one movement skill [28]. The findings in this study explain that students who have good coordination will have good shooting skills using the instep. Also, the research results indicate that coordination is important for each player to improve the ability to shoot using the instep.

This research is reinforced by a theory that in football, especially when shooting at goal, coordination that plays an important role in coordination. Because without coordination, it would be difficult to shoot the goal accurately. One form of eye-body-foot coordination, when the eye sees the target, the body and legs respond to the kick so they can get good accuracy [16].

Therefore, the ability to coordinate is important for a soccer athlete to have in combining the harmony of movement with the ball so that the ball with the foot can be perfect, including in shooting [16], [28].

\subsection{Leg Muscle Power (X1), Balance (X2), and Coordination (X3) with Instep Shooting Ability (Y)}

The results of this study indicate that there is a significant relationship between the three independent variables (coordination, balance, and leg muscle power) and the dependent variable (the ability to shoot using instep). This is because the training program to improve shooting skills uses the instep, through coordination, balance, and leg muscle power exercises first. These three components are the main factors for improving the ability to shoot using the instep.

To be able to shoot well, players must have good physical abilities. Therefore, players are required to be able to shoot well in a narrow space and time. This is because to do a good shooting, players have to do complex movements, these movements can be done if the player has good coordination, balance, and muscle power.

The results of this study are reinforced by a theory that the physical component of leg muscle power is very decisive in shooting, besides that coordination and balance are also important components because in football often kicks, both long-distance kicks and kicks towards the goal, so that players are capable of doing. The full power of shooting hard for a long time is supported by good leg 
muscle power [16]. Players must have the necessary skills (shooting, ball control, coordination) to build and run the game during matches [24].

\section{Conclusions}

The Conclusions showed that: First, There was a relationship between leg muscle power and the shooting ability using the instep. This is reinforced by the results of the p-value $<0.005$, which is $p=0.000$ The results of this study are following the theory, that the ability of a football athlete in shooting football is influenced by leg muscle power because the combination of strength and maximum speed gives an optimal effect on ball kicks [16], [27]. Second, there is a relationship between balance and the ability to shoot using the instep. This is reinforced by the results of the p-value $<0.005$, which is $p=0.000$. This is reinforced by theory, that without having a balance, football players will not be able to shoot properly and accurately, so balance is a component that a football player needs to have [16], [21]. Third, there is a coordination relationship with the ability to shoot using the instep. This is reinforced by the results of the p-value $<0.005$, which is $p=0.000$. The ability to coordinate is important for a soccer athlete to have in combining the harmony of movement with the ball so that the ball with the foot can be perfect, including in shooting [16], [28]. And Fourth, there is a relationship between leg muscle power, balance, and coordination with the shooting ability using the instep. This is reinforced by the results of the $\mathrm{p}$-value $<0.005$, which is $\mathrm{p}=0.000$. The full power of shooting hard for a long time is supported by good leg muscle power [16]. Players must have the necessary skills (shooting, ball control, coordination) to build and run the game during matches [24].

Recommendations for further research are suggested to involve other independent variables (X) that are relevant to this study, such as leg length, running speed, and angle of impact.

\section{Acknowledgments}

The author would like to thank all those who supported this research.

\section{Conflict of Interest}

All authors state that there is no conflict of interest in this study.

\section{REFERENCES}

[1] R. Ardian, S. Suharjana, and E. Burhaein, "Effect of progressive and repetitive part methods against the accuracy of kicking in football extracurricular students," ScienceRise, vol. 1, no. 7, pp. 40-44, 2019. DOI: $10.15587 / 2313-8416.2019 .174318$

[2] I. Serbetar, J. M. Loftesnes, and I. Prprovic, "Disparities in Motor Competence between Roma and Non-Roma Children in Croatia and Relations of Motor Competence , School Success and Social Economic Status," Int. J. Hum. Mov. Sport. Sci., vol. 7, no. 2, pp. 19-24, 2019. DOI: 10.13189/saj.2019.070201

[3] E. Burhaein, "Pembelajaran dalam Pandemi COVID-19: Mengapa Pendidikan Jasmani Adaptif Penting untuk Siswa Disabilitas di Sekolah Luar Biasa," in Disrupsi Strategi Pembelajaran Olahraga: Serta Tantangan dalam Menghadapi New Normal selama masapandemi Covid-19, Tulungagung: Akademia Pustaka, 2020, pp. 187-196.

[4] K. J. Stone and J. L. Oliver, "The Effect of 45 Minutes of Soccer-Specific Exercise on The Effect of 45 Minutes of Soccer- Specific Exercise on the Performance of Soccer Skills," Int. J. Sport Physiol. Perform., vol. 4, no. 1, pp. 163175, 2009. DOI: 10.1123/ijspp.4.2.163

[5] D. T. P. Phytanza, E. Burhaein, S. Sukoco, and S. W. Ghautama, "Life Skill Dimension based on Unified Sports Soccer Program in Physical Education of Intellectual Disability," Yaşam Becerileri Psikol. Derg., vol. 2, no. 4, pp. 199-205, 2018. DOI: 10.31461/ybpd.453865

[6] I. D. Purnomo, T. Tomoliyus, and E. Burhaein, "Development of Learning Activities Playing a Ball on a Goal To Improve Manipulative Skills For Lower Class Students," Proc. 1st Int. Conf. Sci. Technol. an Internet Things, 2019.

[7] D. T. P. Phytanza and E. Burhaein, "Aquatic activities as play therapy children autism spectrum disorder," Int. $J$. Disabil. Sport. Heal. Sci., vol. 2, no. 2, pp. 64-71, 2019. DOI: 10.33438/ijdshs.652086

[8] M. Zago et al., "Dribbling determinants in sub-elite youth soccer players Click for updates Dribbling determinants in sub-elite youth soccer players," J. Sports Sci., vol. 34, no. 5, pp. 411-419, 2015. DOI: 10.1080/02640414.2015.1057210

[9] H. Taskin, "Evaluating sprinting ability, density of acceleration, and speed dribbling ability of professional soccer players with respect to their positions," J. Strength Cond. Res., vol. 22, no. 5, pp. 1481-1486, 2008. DOI: 10.1519/JSC.0b013e318181fd90

[10] E. Burhaein, "Aktivitas Fisik Olahraga untuk Pertumbuhan dan Perkembangan Siswa SD," Indones. J. Prim. Educ., vol. 1, no. 1, pp. 51-58, 2017. DOI: 10.17509/ijpe.v1i1.7497

[11] B. C. H. Huijgen, M. T. Elferink-Gemser, W. Post, and C. Visscher, "Development of dribbling in talented youth soccer players Technical skills aged 12-19 years: A longitudinal study," J. Sports Sci., vol. 28, no. 7, pp. 689698, 2010. DOI: 10.1080/02640411003645679

[12] AFC, "Fitness training in soccer II." Champaign, Bangsborport, 2012.

[13] R. Bahtra, M. Asmawi, and F. Dlis, "Improved VO 2Max : The Effectiveness of Basic Soccer Training at a Young Age," Int. J. Hum. Mov. Sport. Sci., vol. 8, no. 3, pp. 97-102, 2020. DOI: $10.13189 /$ saj.2020.080304 
[14] E. Burhaein, "Aktivitas Permainan Tradisional Berbasis Neurosainslearning Sebagai Pendidikan Karakter Bagi Anak Tunalaras," J. Sport. J. Penelit. Pembelajaran, vol. 3, no. 1, p. 55, 2017. DOI: $10.29407 /$ js_unpgri.v3i1.580

[15] A. Sabdono, P. Sutapa, and D. T. P. Phytanza, "Development of skill training model attacking futsal by using small game-side 3 vs 3 to improve basic skill on high school student," Sci. J. Sci., vol. 7, no. 60, pp. 45-49, 2019. DOI: $10.15587 / 2313-8416.2019 .174680$

[16] A. Ali, "Measuring Soccer Skill Performance: A Review Measuring soccer skill performance: a review," Scand. J. Med. Sci. Sport, vol. 21, no. 2, pp. 170-183, 2011. DOI: 10.1111/j.1600-0838.2010.01256.x

[17] S. Bozkurt and V. Kucuk, "Comparing of Technical Skills of Young Football Players According to Preferred Foot," Int. J. Hum. Mov. Sport. Sci., vol. 6, no. 1, pp. 19-22, 2018. DOI: 10.13189/saj.2018.060103

[18] J. R. Fraenkel, N. E. Wallen, and H. H. Hyun, How to design and evaluate research in education. New York: Mc Graw Hill, 2012.

[19] D. T. P. Phytanza and E. Burhaein, "The Effects of Tenure, Teacher Certification, and Work Motivation on Special Needs Teacher Performance," Univers. J. Educ. Res., vol. 8, no. 9, pp. 4348-4356, 2020. DOI: 10.13189/ujer.2020.0809 62

[20] Topend Sports, "Standing Long Jump Test (Broad Jump)," 2020. [Online]. Available:https://www.topendsports.com/te sting/results/standing-long-jump.htm.

[Accessed: 19-Aug-2020].

[21] J. P. Ambegaonkar, S. V Caswell, J. B. Winchester, Y. Shimokochi, N. Cortes, and A. M. Caswell, "Research Quarterly for Exercise and Sport Balance Comparisons
Between Female Dancers and Active Nondancers Balance Comparisons Between Female Dancers and Active Nondancers," Res. Q. Exerc. Sport, vol. 84, no. 1, pp. 24-29, 2013. DOI: $10.1080 / 02701367.2013 .762287$

[22] N. Tsigilis, E. Zachopoulou, and T. Mavridis, "Evaluation Of The Specificity Of Selected Dynamic Balance Tests," Percept. Mot. Skills, vol. 92, no. 3, pp. 827-833, 2001. DOI: 10.2466/pms.2001.92.3.827

[23] J. P. Ambegaonkar et al., "Ankle stabilizers affect agility but not vertical jump or dynamic balance performance," Foot ankle Spec., vol. 4, no. 6, pp. 354-360, 2011. DOI: $10.1177 / 1938640011428509$

[24] L. H. P. Vieira et al., "Construct validity of tests that measure kick performance for young soccer players based on cluster analysis: Exploring the relationship between coaches rating and actual measures," J. Sports Med. Phys. Fitness, vol. 57, no. 12, pp. 1613-1622, 2017. DOI: $10.23736 / \mathrm{S} 0022-4707.16 .06863-8$

[25] A. Ali et al., "Reliability and validity of two tests of soccer skill," J. Sports Sci., vol. 25, no. 13, pp. 1461-1470, 2007. DOI: 10.1080/02640410601150470

[26] R. M. Kaplan and D. P. Saccuzzo, Psychological testing: Principles, applications, and issues. Wadsworth: Cengage Learning, 2013.

[27] S. Nimphius, M. R. McGuigan, and R. U. Newton, "Relationship between strength, power, speed, and change of direction performance of female softball players," $J$. Strength Cond. Res., vol. 24, no. 4, pp. 885-895, 2010. DOI: 10.1519/JSC.0b013e3181d4d41d

[28] A. A. Poulsen and J. M. Ziviani, "Can I play too? Physical activity engagement of children with developmental coordination disorders," Can. J. Occup. Ther., vol. 71, no. 2, pp. 100-107, 2004. DOI: 10.1177/000841740407100205 